\title{
Learning from the Chinese Model of Development and Moulding China - Sri Lanka Relations
}

\author{
M. I. M. $\operatorname{Irfan}^{1} \&$ M. A. M. Fowsar ${ }^{2}$ \\ ${ }^{1}$ Interdisciplinary Unit, Department of Arabic Language, South Eastern University of Sri Lanka, Sri Lanka \\ ${ }^{2}$ Department of Political Science, South Eastern University of Sri Lanka, Sri Lanka \\ Correspondence: M. I. M. Irfan, Interdisciplinary Unit, Department of Arabic Language, South Eastern University \\ of Sri Lanka, University Park, Oluvil, P.O.Box: \#32360, Sri Lanka. E-mail: irfanibrahim86@seu.ac.lk
}

Received: July 1, $2020 \quad$ Accepted: July 27, $2020 \quad$ Online Published: August 17, 2020

doi:10.5539/jpl.v13n3p57 URL: https://doi.org/10.5539/jpl.v13n3p57

\begin{abstract}
The Chinese model of development is a grand global strategy for achieving the Chinese dream through existing foreign policy. China - Sri Lanka bilateral relations have proved to be of increasingly prominent regional and global significance. The paper tries to examine the state of the China - Sri Lanka economic relationship in the context of the Chinese model of development. It is a descriptive study based on secondary data gathered from various sources of information. The Chinese model of development holds much appeal to many developing countries. However, this model is facing serious challenges and has become the subject of much debate in the recent past. The China - Sri Lanka relations have existed more than two thousand years because of the Island of Sri Lanka's strategic location on the old shipping lane. Sri Lanka is still considered a vital part of the String of Pearls concept. Hence, China has turned its attention towards Sri Lanka. From the beginning of the $21^{\text {st }}$ century, Sri Lanka and China ratified several agreements on bilateral issues relating to the Belt and Road Initiative and Silk Road project. The recent developments in the China - Sri Lanka relationship have led to the creation of a so-called Chinese Colony in the South Asian region, and it has triggered China - India geopolitical interests in the Indian Ocean region. This paper concludes with the argument that the Sri Lankan Government will have to be receptive and sensitive on these issues, and pay attention to controlling contamination and maintaining diplomatic relations with all for the political stability and economic prosperity of the nation.
\end{abstract}

Keywords: Chinese model, development, bilateral relations

\section{Introduction}

The relationship between China and Sri Lanka has a very long history. It dates back to the fourth century AD, and a Chinese monk Faxian visited Sri Lanka during this period. Relations between China and Sri Lanka were renewed since Sri Lanka's independence. Especially in the 1950s, China recognized Sri Lanka and developed commercial ties with Sri Lanka. As a part of this, the Rubber-Rice Pact was signed between the two countries in 1952. This is the first time China signed an agreement with a non-communist state. Then, the relationship between China and Sri Lanka was expanded in many areas.

Diplomatic relations between China and Sri Lanka were established in 1957. As part of this, Sri Lankan Prime Minister Sirimavo Bandaranaike visited China in 1962 and signed an economic and technical cooperation agreement between the two countries. Through these agreements, Sri Lanka received many benefits from China. The Bandaranaike Memorial International Conference Hall (BMICH) was built with China's assistance. They also signed agreements in 1963 to develop maritime trade relations. Since the 1980s, various agreements were signed, and some joint committees were formed to promote bilateral ties. The China-Sri Lanka relationship was further expanded after the 1990s (Asirwatham, 2018).

Presently, China - Sri Lanka bilateral relationship is acquiring increasing regional and global significance. Both countries have had extensive historical economic links, which continue to date, and it has risen sharply in recent years, focusing on several areas, including economic development, the military and diplomacy. China extended military assistances along with other Asian powers to fight against Tamil rebels during the final stage of the war and contributed to the construction of the Hambantota port in Southern Sri Lanka. Emerging trends in China - Sri Lanka relations have caused panic among the countries in the Indian Ocean region (Samaranayake, 2011). 
China focuses on several aspects, such as the Chinese model of economic development, Belt and Road Initiative (BRI), $21^{\text {st }}$ Century Maritime Silk Road, and other economic globalization approaches. These strategic interestbased moves have become the central foreign policy project of China. The Sri Lankan Government has engaged with China on the BRI and Silk Road and followed the Chinese model of development, under which many economic projects showed remarkable growth, leading to rapid development in Sri Lanka. Especially after the civil war, Chinese development contributions helped to rebuild the war-torn island nation.

The Chinese development model strategy resulted in many bilateral economic initiatives between China and Sri Lanka, as witnessed by several agreements signed by both countries in the $21^{\text {st }}$ century. Thus, it is called Chinacentric development era in Sri Lanka and prompting many to say that Sri Lanka has become a Chinese colony in the Indian Ocean region. However, this development project has faced serious challenges and become the subject of much debate because it promoted enlightened authoritarianism and neo-colonialism.

The geopolitical realities of South Asia and India's concerns over Sri Lanka have challenged Sri Lanka's relationship with China. India does not support China's efforts to establish domination in the Indian Ocean region, and it is cautious about establishing Indian dominance in the South Asian region. In this context, the paper attempts to explore the state of the China-Sri Lanka economic relationship in the light of the Chinese model of development. It is a qualitative study based on secondary data derived from journal articles, book chapters and reports.

\section{Chinese Model of Development}

The Chinese model of development has significantly contributed to the rapid economic growth in China. The main objective of this model is to achieve economic growth by controlling political freedom in the country. Many countries in the world are trying to adopt China's development model to boost their economy. China has presently attracted substantial foreign direct investments, and thus it has become the world's largest trading nation with a considerable amount of foreign reserve. China's development model has also driven industrialization, marketization, urbanization and globalization.

The Chinese development model protects the state-owned economic system with its vested interests and strategies. It also undertakes a high level of financial management without political constraints. This model of development has liberated itself from traditional socialism and embedded the market system into the economy. According to $\mathrm{Li}$ (2015), there are four main pillars of China's development approach. They are the state-led development, prioritizing development, focusing on good governance and implementing systematic and feasible reforms.

Pan Wei (2007) argued that the Chinese model is based on four unique approaches, which are, developing the economy, social organization, effective government, and outlook on the world. China follows the state-controlled model of development, and it mostly invests in economic and infrastructure development. In particular the Chinese government currently focuses on developing infrastructure facilities, such as highways, seaports, electricity, railway and aviation networks, on boosting industrial growth.

Many developing countries find the Chinese model attractive because it has mainly contributed to development in the past decades due to the following reasons. First, China has become the leading economy in the world, allowing the state-controlled model of development, and it maintains socio-economic and political stability under the oneparty rule while accommodating its ideological principles. Second, the Chinese model appears to provide an innovative strategy to address socio-economic problems, including poverty and establish good governance. Third, the Chinese model is rooted in its own value-free diplomatic doctrine, which has attracted many developing countries.

However, the Chinese model of development is facing serious challenges and has become the subject of much debate due to the perception that it promotes enlightened authoritarianism and neo-colonialism. According to $\mathrm{Li}$ (2015), China is in a satisfactory position in its development model. However, there are many criticisms about it. The austerity measures followed in China's domestic politics have prevented the realities from emerging. Those who insist on the Chinese model of development need to present comprehensive information with practical evidence to make it clear to the people. The understanding of how far the Chinese model has succeeded in practice is essential. There are allegations among analysts that no clear interpretations have been put forward in this regard. Some economists criticize the Chinese model as a vague innovation.

Another challenge is that Chinese citizens are not satisfied with their development model because of China has multiple problems, including corruption, unbalanced growth and inequality, lack of democracy, human rights violations, and lack of the rule of law. For example, China's western provinces are less developed than its other regions. According to Meine Pieter vans Dijk (2011), inequality exists in China between urban and rural farmers. Especially, Tibet and Qinghai provinces in China are less developed regions. The fact is, the Chinese model of 
development has certain clear fault lines due to its lack of moral appeal, its purely pragmatic approach, and its ineffective handling of many critical dimensions of human development within China.

The Chinese development model is vastly different from the Western development model because it is based on political stability under the one-party rule and a state-controlled economy. The Western development model consists of liberal democratic principles and the market-oriented open economic policy. Sometimes, this model of development is called the Washington consensus, and it tries to introduce liberal democratic traditions and freemarket economy across the world. The world bank and international monetary fund are major driving forces of this type of development. In the present era, most of the countries have adopted the Western model of development to boost their economic development.

However, Suisheng Zhao (2010) dismisses the Beijing consensus as a saga since the Chinese government did not firmly follow its own doctrines when implementing the China model. It had to strike a balance between economic growth and political stability, a market-based economy and a dictatorial state. Such efforts had to be made in order to sustain its economic growth during its modernization efforts.

In sum, we can mention that the Chinese model of development is a merger of pragmatism, gradualism, economic development and political oppression, contrary to the Western model, which is a combination of the free-market system and liberal democracy. The Sri Lankan Government has indeed been following the Chinese model of development. The Chinese model has done remarkably well by rapidly achieving infrastructure development; especially after the civil war, economic growth led to the national development and contributed toward rebuilding the country.

\section{Historical Relations}

The two countries have always had a healthy relationship. China and Sri Lanka had enjoyed friendly relations from even before the time Sri Lanka (Ceylon) obtained independence. This encompassed long-term cultural ties, similar foreign policies, infrastructure development assistance and mutually beneficial cooperation. Many kings of Sri Lanka visited China in the first and second centuries, and such visits became more frequent after the fourth century (Senaveratne \& Levi, 1916).

In the fifth century, China's renowned monk Faxian came to Sri Lanka to study Buddhism. He stayed for two years during the reign of King Mahanama (Deyshappriya, 2016). Later, during the Chinese Ming Dynasty, a navigator named Zheng He visited Sri Lanka three times in succession in the $15^{\text {th }}$ century (Weihua, 2013). These were two significant occasions that occurred in the long history of foreign relations between China and Sri Lanka.

The formal or official relations between China and Sri Lanka started at the beginning of 1950 when China acknowledged Sri Lanka as an independent nation. A bilateral economic agreement known as the Sino-Lanka Rubber-Rice Pact was signed in 1952 and subsequently, the trade relationships began. In 1957, the two countries formally established diplomatic ties (Weihua, 2013). The first bilateral trade agreement between the two countries was being restored every five years until 1982. This agreement allowed Sri Lanka to import 270,000 metric tons of rice from China annually, and agreed to China to import 50,000 tons of rubber from Sri Lanka per year for five years (Deyshappriya, 2016). Further, the Superior Courts Complex and Bandaranaike Memorial International Conference Hall were completed with Chinese cooperation after 1972.

In the $21^{\text {st }}$ century, Sri Lanka and China enjoyed an excellent and friendly relationship. In April 2005, the two countries announced the establishment of Sri Lanka - China All-round Cooperation Partnership of Sincere Mutual Support and Ever-lasting Friendship (Weihua, 2013). Sri Lanka received the second-highest loan amount granted by China. At present, the close contact between the two countries and the active cultivation of economic cooperation programs by the present government have resulted in the granting of huge loans by the Chinese government for infrastructure development.

\section{Agreements and Infrastructure Development}

In recent years, the development of crucial seaports under the so-called String of Pearls project has contributed remarkably toward greater economic cooperation between China and Sri Lanka. China is one of the most leading economies across the world. China is presently the biggest trading partner of Sri Lanka within the South Asian region. In keeping with the sound relations between Sri Lanka and China, the two countries continue to sustain diplomatic connections and enhanced governmental communication, while supporting each other's initiatives and efforts to safeguard their territorial integrity, sovereignty, and independence.

In the beginning, China and Sri Lanka did not have a close relationship on the diplomatic and ideological front since both countries followed different strategies and policies in various spheres. Despite the variations between their political and diplomatic perspectives, the two countries cooperated in signing several trade pacts. Some of 
these were China-Sri Lanka trade agreements entered into during the period from 1977 to 1982 . Later, the agreement on trade and economic cooperation was signed in 1984. China -Sri Lanka business council was also instituted in 1994 (Premadasa, 2007). These bilateral agreements provided the opportunity for Sri Lanka to take forward all-round development of the country according to its national strategies and development needs while taking into consideration the regional situation as well.

Beginning from the $21^{\text {st }}$ century, Sri Lanka and China became involved in many bilateral economic programs. Several agreements were made between both countries, and the era of China-centric development projects commenced on the Island of Sri Lanka. During the period 2003-2016, both countries, after holding many meetings, signed several Memorandum of Understandings (MoUs) and agreements. Former President Mahinda Rajapaksa, currently Prime Minister of Sri Lanka signed several bilateral agreements, such as the Economic and Technical Cooperation agreement, and the Friendship City Relationship agreement between the city of Guangzhou in China and the District of Hambantota in Sri Lanka (Deyshappriya, 2016). There was also an inter-bank agreement between the China Development Bank and the Central Bank of Sri Lanka, which entered into an Investment Facilitation Agreement to strengthen the long-term economic linkages between the two banks. All of these MoUs are considered significant for Sri Lanka's future development.

In the recent decade, China-funded many infrastructure development projects to assist Sri Lanka's post-war development initiative. In those projects, the Hambantota Sea Port, Mattala Rajapaksa International Airport, Colombo Port Complex, Colombo Container Terminal, Norochcholai Power Station, Southern Expressways, Northern Road Rehabilitation Project (A9 road), Nelum Pokuna Theater, the Colombo-Katunayake Expressway and Lotus Tower in Colombo are remarkable Chinese funded projects. These development projects have become the new emblems of China-Sri Lanka friendship. All of these projects were completed under Chinese cooperation extended since 1972 (Table 1).

Table 1. Chinese funded projects in Sri Lanka

\begin{tabular}{lcc}
\hline \multicolumn{1}{c}{ Name of the Project } & Cost (US\$ Million) & Year Completed \\
\hline Completed Superior Court Complex & 3.58 & 1972 \\
Bandaranaike Memorial International Conference Hall & 2.14 & 1973 \\
Exclusive Economic Zone at Mirigama & 28 & 2009 \\
Norochcholai Power Station & 1400 & 2011 \\
Lotus Pond Theatre & 30 & 2011 \\
Colombo-Katunayake Expressway & 248.2 & 2013 \\
Colombo South Container terminal & 2.4 & 2013 \\
Mattala International Airport & 210 & 2013 \\
Hambantota Port Development Project (Phase I \&II) & 461 & 2014 \\
Moragahanka Reservoir Project (Stage I) & 370 & 2014 \\
\hline
\end{tabular}

Source: Created by the author based on Hariharan (2013), Deyshappriya (2016).

In 2017, the Government of Sri Lanka signed a Public-Private Partnership agreement with the China Merchants Port Holdings (CMPH) for US\$ 1.12 billion to develop Hambanthota Harbour and its surroundings (Wang \& Ye, 2019). In 2018, the Ministry of Megapolis and Western Development of Sri Lanka signed an agreement with the China Petroleum Pipeline Engineering (CPPE). In addition, the Chinese government approved a $\$ 1$ billion loan for the first phase of the expressway between Colombo and Kandy. In March 2018, Bank of China opened its first branch in Sri Lanka. The Prime Minister of Sri Lanka Ranil Wickremesinghe was present at the opening ceremony (Singh, 2018).

In April 2018, China Railway Beijing Engineering Group was awarded a contract to build 40,000 houses in the Jaffna District of Sri Lanka at the cost of US \$300,000 million. During the visit of Maithripala Sirisena, the President of Sri Lanka to China in May 2019, various steps were taken to elaborate bilateral relations. China has agreed to supply $\$ 14$ million worth of military equipment and 150 police vehicles. China also provided a gift to the president to set up a kidney hospital in the Polonnaruwa district of Sri Lanka. China was interested in supplying medical equipment during the Easter Sunday suicide attack and the spread of COVID19. The present government, 
headed by President Gotabhaya Rajapaksa maintains excellent relations with China (Singh, 2020). After the formation of the new government, China's involvement in Sri Lanka has also been increasing.

\section{Belt and Road Initiative and Sri Lanka}

President Xi Jinping announced the Belt and Road Initiative (BRI), formerly known as One Belt One Road (OBOR), in 2013. China aimed to regain the historical magnificence of the earliest Silk Route through its BRI initiative, which has become the most substantial economic and diplomatic undertaking across the world. Its objective is to connect around sixty-six countries from East to West. The Belt and Road Initiative symbolizes China's projected Silk Road Economic Belt and Maritime Silk Road (Asees, 2016). The Belt and Road Initiative includes five main thrusts areas, such as unimpeded trade, infrastructure construction, financial integration, policy coordination, and people-to-people bonds. The Chinese government' interest and active role in promoting the BRI have reflected in the current economic and trade relations between Sri Lanka and China. The Island of Sri Lanka's strategic location in the centre of the maritime Silk Road provides the country with the opportunity of serving as an important trading hub in the region.

The BRI has been toughly linked to infrastructure connectivity in Sri Lanka. However, there is still very little consciousness of the initiative among the citizens of Sri Lanka. Two mega projects, the Colombo Port City project and Hambantota Harbor project came under the straight efforts of the BRI in Sri Lanka. Former Prime Minister Ranil Wickremasinghe (2016) announced that the Chinese government had discussed with the Sri Lankan government, with a plan to establish a BRI hub in the Indian Ocean. He added that this was expected to allow closer cooperation between the two countries and that the Colombo port and the Southern port are initiatives of the BRI. In future, the Northern port, Western port and Trincomalee port (Eastern) will also be included in direct action of the BRI in Sri Lanka.

Recently, a large number of people had protested against the land acquisition that was going on for establishing an industrial zone in Hambantota district in Sri Lanka. However, the Sri Lankan government said it would discuss with Chinese authorities and review the Belt and Road Initiative. While presenting the budget speech in parliament in April 2017, Former Finance Minister Ravi Karunanayake said that Sri Lanka would play a substantial part in the Chinese government's development initiative. For many years, China has played a crucial role in contributing to Sri Lanka's economic and infrastructure development, especially since the end of the 30-year war between the Sri Lankan military and the LTTE in 2009. The Chinese government initiated many development projects, including establishing new highways, a new airport and port, and infrastructure development. Several other projects are presently underway to develop the war-torn country (The Sunday Leader, 2016).

Still, there is very little support for this BRI commitment in Sri Lanka. Until now, Sri Lanka's experience with the BRI has been very closely linked to infrastructure development, with less emphasis on other areas that should be a priority in cooperation between the two countries. Although the BRI appears to be a promising one for Sri Lanka, it is difficult to take full advantage of this initiative as it does not have a comprehensive plan. At the same time, it is difficult to assess its long-term benefits and implications for the country. Sri Lanka will receive more benefits if more comprehensive information is provided on the BRI to fix how best the efforts could be turned into tangible outcomes for the country in the coming years. However, Sri Lanka has extensively received China's support and cooperation through the ongoing Belt and Road Initiative. Sri Lanka will no doubt be part of China's Belt and Road Initiative as we look at the close relationship between the two countries. It may contribute to transform Sri Lanka into a trading hub in the Indian Ocean by investing and handling ports, airports and industrial zones in the southern part of the country.

\section{6. $21^{\text {st }}$ Century Maritime Silk Road and Sri Lanka}

The Religious, Cultural and Historical relationships between Sri Lanka and China began several centuries ago. The relationship that was established during the period of the ancient Silk Route has now been strengthened several-fold. Sri Lanka was one of the countries that maintained contact with China even during the formative stages of the Silk Road. Sri Lanka being an island in South Asia located at the southeastern tip of India, its geographic location and its deep harbours gave it great strategic significance since the time of historical Silk Road and even through World War II. Indeed, this factor is mainly responsible for strengthening the Sino-Lanka (ChinaSri Lanka) economic relationship.

In the Asian continent, the Indian Ocean region is becoming more significant due to the considerable volume of energy supplies and goods that are transported across it daily. Countries bordering the Indian Ocean are geopolitically important, as they are all linked to the busiest sea route in the world. The trade and commercial route in the Indian Ocean constitute the strategic links of all these countries, including China. Sri Lanka enjoys a more crucial strategic position with the rise of the Indian Ocean's reputation and enhancement of its seaports and national 
development and above all, the unique geographical location. Thus, China has been paying more attention to Sri Lanka from the time of its independence.

This is underscored by the fact that at the bilateral level, China and Sri Lanka have signed numerous far-reaching development agreements dealing with the following matters: a durable shared political confidence established between both countries; both countries will treat trade and economic development as a priority in their national policy; Sri Lanka - China bilateral trade and economic cooperations promise excellent opportunities after the Free Trade Area Agreement was signed; the bilateral relationship is raised to a new level after the Chinese government introduced the proposal to construct the $21^{\text {st }}$ Century Maritime Silk Road. The trade and economic cooperation and cultural exchanges will promote the bilateral relations between Sri Lanka and China.

\section{Practical Challenges}

\subsection{Creation of a Chinese Colony}

In December 2016, many protests by people erupted over the acquisition of land for an industrial zone in Hambantota in Sri Lanka. The agreement to lease the port of Hambantota and 15,000 acres of adjoining land to a Chinese state-owned company also raised a lot of controversies. This port and the land were given on a 99-year lease to a Chinese state-owned company with the projected deal valued at $\$ 1.2$ Billion. While this project will boost Sri Lanka's infrastructure, the thorny issue is that this deal will create a Chinese Colony in these parts. This project was creating a lot of sentiment, with many people protesting against the handover of the port to China in December 2016. This will result in the Chinese entity taking over control of the Hambantota Port and the extensive adjoining areas (15,000 acres), including the international airport and various other facilities for the next 99 years.

\subsection{China-India Geopolitical Manoeuvres}

There had been continuous interactions between neighbouring India and distant China from very early times through the land route and the sea route. Now, these interactions will be extended to cover Sri Lanka as well. Indeed, the government of Sri Lanka has tried to maintain a balanced foreign policy in the region when maintaining close links with both these contending regional superpowers. The Indian Ocean region's geopolitical realities is still an obstacle to the Chinese government while promoting foreign relations with the government of Sri Lanka. In this regard, the announcement made by former President Mahinda Rajapaksa in January 2012 in the presence of a group of foreign journalists is more significant. In this announcement, he said that Sri Lanka is not a pearl on China's string. He further expressed the view that Sri Lanka would have more friendly relations with China and India. This issue has been the essential basis of Sri Lanka's balanced foreign policy (Mendis, 2012). However, India's concern over Chinese dominance in Sri Lanka remains high.

\subsection{The Rubber-Rice Pact (1952)}

An agreement was signed between China and Sri Lanka in December 1952 to exchange Sri Lanka's rubber and China's rice. This agreement not only marked a turning point in foreign and economic relations between the two countries but also highlighted the flexibility of Sri Lanka's foreign policy. This deal is timely important for both countries for several reasons. In this regards, Sri Lanka is struggling in maintaining the pact due to the increased rice prices, worldwide rice shortage, falling rubber production and increased production of artificial rubber. The Chinese government has also dramatically improved its trade relations with its friendly nations and found new markets for its import and export activities.

\section{Conclusion}

The Chinese development model is characterized by allowing a certain degree of economic freedom in combination with political suppression. It is a grand global strategy for achieving Chinese national interests. This Chinese model has proved itself attractive to many developing countries. However, the Chinese model of development has been criticized for supporting enlightened authoritarianism and neo-colonization. This model does not seem to have the approval of most Chinese citizens. On the other hand, there are severe criticisms of Chinese debt diplomacy towards developing countries like Sri Lanka.

Sri Lanka and China relations have a long history. Now because of Sri Lanka's tactical position in the region bordering key shipping paths and its potential for being part of the String of Pearls concept, Chinese's attention towards Sri Lanka has tremendously increased in recent decades. In the $21^{\text {st }}$ century, many bilateral economic programs have been drawn up and several agreements signed by both countries to advance mutual relations of both countries. In particular, the BRI and Silk Road projects have become very significant about Sri Lanka's postwar development strategy. However, an argument is growing that Sri Lanka has now become a Chinese colony in the Indian Ocean. In this regards, the government of Sri Lanka should have to move forward strategically to achieve its national interests. 


\section{References}

Asees, M. S. (2016). One belt and one road initiative of China \& its implications in Sri Lanka. Retrieved from https://www.colombotelegraph.com/index.php/one-beltand-one-road-initiative-of-china-its-implications-insri-lanka/

Asirwatham, G. (2018). Overview of Sri Lanka-China relations. Retrieved from https://lki.lk/blog/overview-ofsri-lanka-china-relations/

Deyshappriya, N. P. R. (2016). Sri Lanka - China economic relations in comparative perspective ample room to grow. Retrieved from http://www.lki.lk/wpcontent/uploads/2016/10/Sri-Lanka_China-EconomicRelations_Working-Paper-DPedited_RD-Revised.pdf

Hariharan, R. (2013). China's strategic presence in Sri Lanka. Retrieved from https://www.colombotelegraph.com/ index.php/chinas-strategic-presence-in-sri-lanka/

Li, H. (2015). The Chinese model of development and its implications. World Journal of Social Science Research, 2(2), 128-138. https://doi.org/10.22158/wjssr.v2n2p128

Mendis, P. (2012). The Sri Lankan Silk Road: The potential war between China and the United States. Harvard International Review, 34(2), 54-58.

Premadasa, T. K. (2007). Sri Lanka China trade relationship. Retrieved from http://www.asiantribune.com/node/ 7893

Samaranayake, N. (2011). Are Sri Lanka's relations with China deepening? An analysis of economic, military, and diplomatic data. Asian Security, 7(2), 119-146. https://doi.org/10.1080/14799855.2011.581603

Senaveratne, J. M., \& Levi, M. S. (1916). China-Sinhalese relations in the early and middle ages. The Journal of the Ceylon Branch of the Royal Asiatic Society of Great Britain \& Ireland, 24(68), 74-105.

Singh, G. (2018). Evolution of China-Sri Lanka relations. New Delhi: Vivekananda international foundation. Retrieved from https://www.vifindia.org/sites/default/files/Evolution-of\%20China-SriLanka-Relations.pdf

Singh, S. (2020). China's strategic relations with Sri Lanka. Retrieved from https://southasianvoices.org/chinasstrategic-relations-with-sri-lanka/

The Sunday Leader. (2016). Sri Lanka will work with China's One Belt, One Road Initiative. https://doi.org/10.4467/23538724GS.17.003.6864

van Dijk, M. P. (2011). A different development model in China's Western and Eastern Provinces?. Retrieved from http://file.scirp.org/pdf/ME20110500006_51331573.pdf

Wang, Z., \& Ye, F. (2019). China-Sri Lanka relations in the context of the $21^{\text {st }}$ Century Maritime Silk Road: Motives, Challenges, and Prospects. Asian Perspective, 43(3), $481-503$. https://doi.org/10.1353/apr.2019.0020

Wei, P. (2007). The Chinese model of development. Retrieved from http://fpc.org.uk/fsblob/888.pdf

Weihua, W. (2013). China-Sri Lanka friendly relationship: Historical tradition, realistic dynamics, and brighter $\begin{array}{llll}\text { futures. } & \text { Defense } & \text { Reminar. } & \text { Retrieved }\end{array}$ http://www.defseminar.lk/mediacentre/pres/Dr\%20Wang \%20Weihua \%20.doc.pdf

Wickremasinghe, R. (2016). Sri Lanka and its place in the world. Retrieved from https://www.mfa.gov.lk/pmaddressnz/

Zhao, S. (2010). The China model: can it replace the Western model of modernization. Journal of Contemporary China, 19(65), 419-436. https://doi.org/10.1080/10670561003666061

\section{Copyrights}

Copyright for this article is retained by the author(s), with first publication rights granted to the journal.

This is an open-access article distributed under the terms and conditions of the Creative Commons Attribution license (http://creativecommons.org/licenses/by/4.0/). 